\title{
Long-term flood controls on semi-arid river form: evidence from the Sabie and Olifants rivers, eastern South Africa
}

\author{
GEORGE HERITAGE ${ }^{1}$, STEPHEN TOOTH ${ }^{2}$, NEIL ENTWISTLE ${ }^{3} \&$ \\ DAVID MILAN ${ }^{4}$ \\ 1 AECOM. Exchange Court, 1 Dale Street, Liverpool L2 2ET, UK \\ george.heritage@aecom.com \\ 2 UK Department of Geography and Earth Sciences, Aberystwyth University, Llandinam Building, Penglais Campus, \\ Aberystwyth SY23 3DB, UK \\ 3 University of Salford, Peel Building, University of Salford, Salford M5 4WT, UK \\ 4 Department of Geography, Environment and Earth Sciences, University of Hull, Cottingham Road, Hull HU6 7RX, UK
}

\begin{abstract}
Rivers in the Kruger National Park, eastern South Africa, are characterised by bedrock-influenced 'macrochannels' containing variable alluvial thicknesses and riparian vegetation assemblages. Evidence from the Sabie and Olifants rivers suggests that flows up to moderate floods $\left(<3500 \mathrm{~m}^{3} \mathrm{~s}^{-1}\right)$ tend to result in net alluviation, with sediments gradually covering the underlying bedrock. More extreme floods strip alluvium and erode bedrock, effectively exerting the primary control over long-term river morphologic development. On the Olifants River, post-flood aerial LIDAR imagery reveals that the 2012 extreme flood $\left(\sim 14000 \mathrm{~m}^{3} \mathrm{~s}^{-1}\right)$ resulted in extensive stripping of stored alluvial sediment, exposing and eroding the underlying weathered bedrock. On the Sabie River, preliminary optically stimulated luminescence ages for remnant alluvium are all less than 1000 years, highlighting typical timescales of sediment storage. Together, these results suggest that while periods of general alluviation occur on these systems, long-term river development results from extreme flood-generated bedrock erosion.
\end{abstract}

Key words semi-arid river; channel development; flood impact; Sabie River; Olifants River

\section{BACKGROUND}

Drylands (hyperarid, arid, semi-arid and dry-subhumid regions) cover $\sim 50 \%$ of the Earth's surface and sustain $\sim 20 \%$ of the world's population. They are typically characterised by strong climatic variations, having extended dry periods interspersed with short, intense rainfall events, and are widely considered to be some of the regions most vulnerable to future climate change. Dryland rivers are thus characterised by long periods of very low or no flow, interspersed with infrequent short-lived, extreme flood events (Tooth, 2000). These variable flow regimes combine with erratic sediment supply and diverse riparian vegetation assemblages, and produce channel morphologies and dynamics that differ markedly from humid temperate rivers. The impact of hydroclimatic drivers on the morphological development of these dryland systems is little known as lengthy (multi-decadal) observational records of channel response to these flow regimes are limited. This paper integrates field and aerial image evidence and preliminary luminescence dates from the Sabie and Olifants rivers in South Africa to provide new insight into the long-term functioning of these systems.

\section{STUDY SITES}

The Sabie and Olifants rivers are located in the southern and central part of the Kruger National Park in the Mpumalanga and Limpopo provinces of north-eastern South Africa (Fig. 1). The $54570 \mathrm{~km}^{2}$ Olifants catchment flows off the Highveld Plateau $(\sim 2000-1500 \mathrm{~m})$, descending the Drakensberg Escarpment onto the Lowveld ( $400-250 \mathrm{~m})$. The Sabie River drains a $6320 \mathrm{~km}^{2}$ semi-arid catchment rising in the Drakensberg Mountains to the west (1600 m a.s.l.) and descends rapidly onto the low-relief Lowveld (400 $\mathrm{m}$ a.s.1.) and Lebombo zones (200 $\mathrm{m}$ a.s.l.) in the east. Rainfall in both catchments is greater in the highland areas $(2000 \mathrm{~mm} /$ year $)$ and declines rapidly towards the South Africa-Mozambique border $(450 \mathrm{~mm} /$ year $)$. Although water abstractions have altered the low flow regimes (generally below $50 \mathrm{~m}^{3} \mathrm{~s}^{-1}$ ) of both rivers, flood flows are unaffected, and the channels remain unimpacted by engineering structures or other human activities over considerable lengths within the National Park. Thus, they represent excellent, near-pristine sites for investigating semi-arid, bedrock-influenced channel dynamics. 


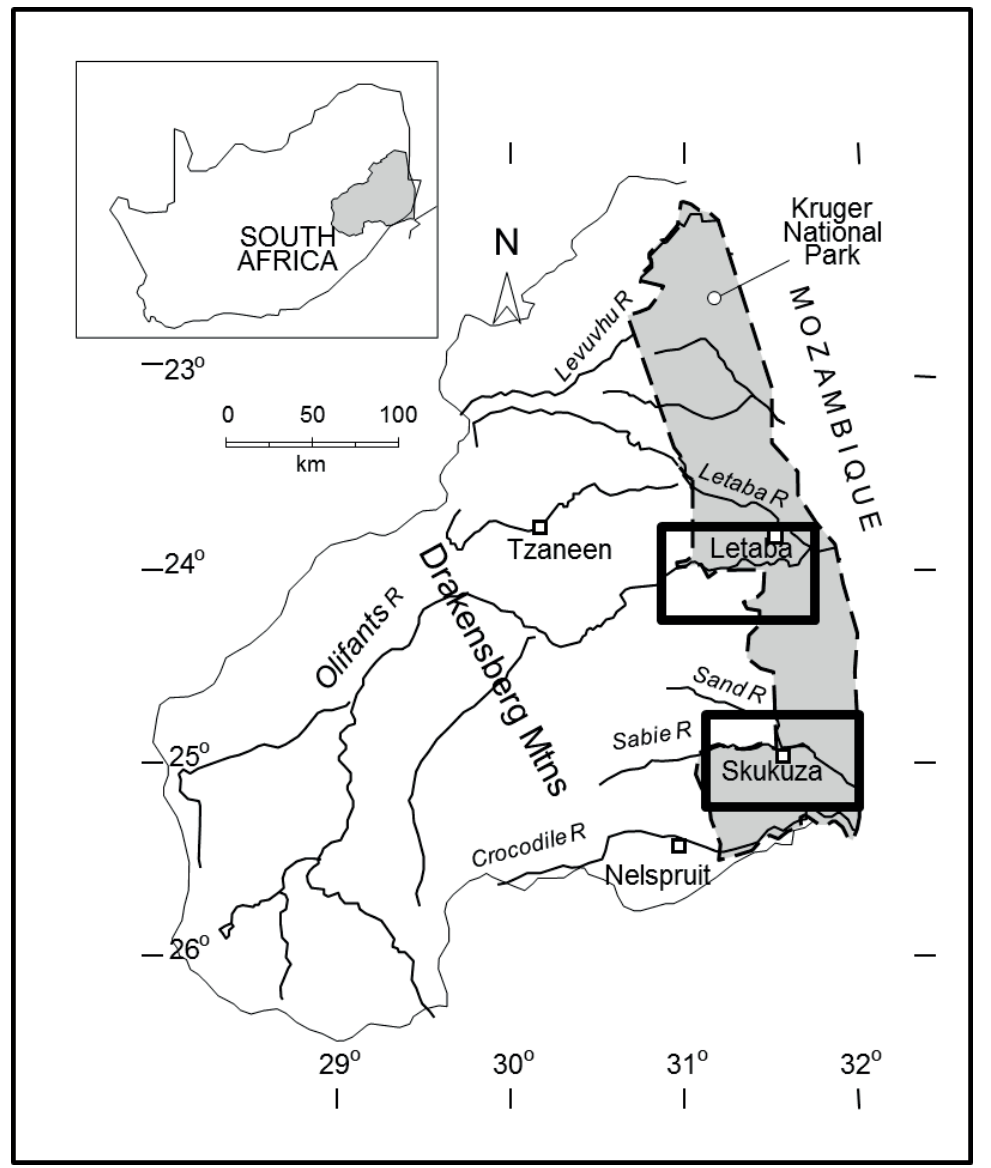

Fig. 1. Location of Sabie and Olifants rivers in north-eastern South Africa. Black boxes indicate the extent of the study reaches.

In the National Park, both rivers are characterised by a bedrock macrochannel, which extends across the floor of a 10-20 m deep 'valley' incised into the Lowveld. Outside of the macrochannel, floods have a very infrequent and limited influence. Along with variable flow regimes and sediment loads, these rivers are thus characterized by a high degree of bedrock influence, although the bedrock may be buried by alluvial sediments of varying thickness. The diverse underlying geology results in frequent, abrupt changes in macrochannel slope and associated sediment deposition patterns, creating diverse channel types that include alluvial single thread and braided channels, and bedrock-influenced anastomosed and pool-rapid channels (van Niekerk et al., 1995). This paper presents some of the preliminary findings of a field and aerial data collection campaign, conducted in response to the Cyclone Dando flood in January 2012. Information on channel topography, morphology and sedimentology are presented alongside preliminary optically stimulated luminescence (OSL) ages for basal sediments of the Sabie River to reconstruct longterm sediment and morphological dynamics.

\section{FLOW DRIVEN SEDIMENT STORAGE AND MORPHOLOGIC CHANGE}

LIDAR data for a $50 \mathrm{~km}$ reach of the Sabie River that was collected following the 2012 extreme flood $\left(5500 \mathrm{~m}^{3} \mathrm{~s}^{-1}\right)$ was compared with archive data that was flown in 2004 after the 2000 extreme flood $\left(\sim 7000 \mathrm{~m}^{3} \mathrm{~s}^{-1}\right)$. Both surfaces had vegetation removed and the difference between the two surfaces represents extreme flood-driven erosion and deposition along the study reach. DEM differencing revealed net erosion of $920348 \mathrm{~m}^{3}$ over the $50 \mathrm{~km}$ reach. When analysed at the channel type scale using the classification of Van Niekerk et al. (1995), no consistent response pattern can be deduced (Table 1), with both net erosion and deposition occurring across the channel types. 
Table 1 Erosion and deposition values $\left(\mathrm{m}^{3} / \mathrm{m}^{2}\right)$ for reaches along the Sabie River, South Africa, which are attributed to the Cyclone Dando flood in January 2012.

\begin{tabular}{|c|c|c|c|c|c|c|}
\hline \multirow[t]{2}{*}{ Channel type } & \multicolumn{3}{|c|}{ Individual reach } & \multicolumn{3}{|c|}{ Reach average } \\
\hline & Deposition & Erosion & Difference & Deposition & Erosion & Difference \\
\hline \multirow{3}{*}{$\begin{array}{l}\text { Bedrock } \\
\text { anastomosed } \\
\text { reaches }\end{array}$} & 0.129 & 0.210 & -0.081 & & & \\
\hline & 0.174 & 0.213 & -0.039 & & & \\
\hline & 0.152 & 0.096 & 0.057 & 0.152 & 0.173 & -0.021 \\
\hline \multirow[t]{3}{*}{ Braided reaches } & 0.070 & 0.483 & -0.413 & & & \\
\hline & 0.114 & 0.297 & -0.183 & & & \\
\hline & 0.236 & 0.063 & 0.174 & 0.140 & 0.281 & -0.141 \\
\hline \multirow[t]{3}{*}{ Pool-rapid reaches } & 0.192 & 0.133 & 0.059 & & & \\
\hline & 0.135 & 0.202 & -0.067 & & & \\
\hline & 0.260 & 0.115 & 0.145 & 0.196 & 0.150 & 0.046 \\
\hline Single thread reach & 0.320 & 0.107 & 0.213 & 0.320 & 0.107 & 0.213 \\
\hline \multirow{6}{*}{$\begin{array}{l}\text { Mixed } \\
\text { anastomosed } \\
\text { reaches }\end{array}$} & 0.095 & 0.368 & -0.273 & & & \\
\hline & 0.061 & 0.316 & -0.255 & & & \\
\hline & 0.187 & 0.251 & -0.063 & & & \\
\hline & 0.171 & 0.378 & -0.207 & & & \\
\hline & 0.293 & 0.128 & 0.166 & & & \\
\hline & 0.144 & 0.172 & -0.028 & 0.159 & 0.269 & -0.110 \\
\hline Overall & 0.171 & 0.221 & -0.050 & & & \\
\hline
\end{tabular}

This inconsistent response shown by channel type is contrary to the findings from the 2000 extreme flood on the Sabie reported by Heritage et al. (2004), when morphologic change better reflected the pre-flood channel type pattern, with anastomosed reaches exhibiting consistent sediment loss and pool-rapid areas accumulating uncohesive sands. Sediment loss appears to be more general following the 2012 event, with an overall shift towards more bedrock-dominated channel types, namely the bedrock anastomosed, mixed anastomosed, and pool-rapid channel types (Fig. 2). Of particular note is the effect of flood event sequencing. Considerable stripping of sediment from mixed anastomosing reaches occurred during the 2000 flood, leaving isolated sediment remnants that were then exposed to the full force of the 2012 flood. Rather than being protected as part of a larger coherent cohesive depositional feature, these remnant sediments were eroded further in the 2012 flood. This could indicate that once stripping has started, remnant features become vulnerable to erosion unless prolonged sedimentation reincorporates them into new depositional features. Without this morphologic 'recovery', the trend is for further stripping by extreme flows back to a bedrock template. Morphologic recovery is thus dependent on sedimentation during prolonged periods of low and moderate floods free from extreme events. This temporal pattern has also been observed along the Olifants River, where previously extensive cohesive alluvial deposits in mixed anastomosed reaches were stripped down to bedrock by the

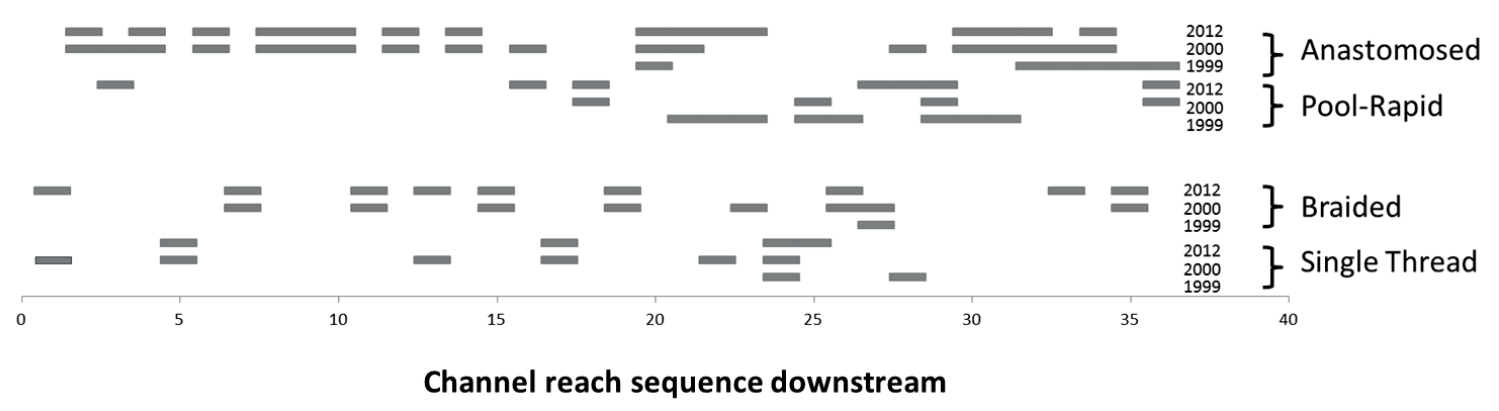

Fig. 2 Channel type change over a $106 \mathrm{~km}$ length of the Sabie River in response to the cyclone-driven floods of 2000 and 2012. The 'anastomosed' category includes both bedrock anastomosed and mixed anastomosed types (note shorter study reach in 2012). 
2012 extreme event. This observed sequence of channel type changes supports the developmental model for semi-arid, bedrock-influenced channels hypothesised by Rowntree et al. (2001), but provides additional evidence of the hydroclimatic conditions and process drivers responsible for channel change.

\section{LONG-TERM SEQUENCING OF SEDIMENT STRIPPING}

Insight into the rates of sediment recycling in semi-arid, bedrock-influenced systems can be gained by determining the the initial stages of general alluviation that follow extensive stripping events and thus provide a guide to sediment storage timescales and the longevity of channel depositional features. Basal sedimentary deposits were exposed on a number of different depositional features along the Sabie River following the 2000 flood event, and samples were collected for optically stimulated luminescence (OSL) dating (Fig. 3).

Table 2 Optically stimulated luminescence ages from basal sediments on the Sabie River, South Africa*).

\begin{tabular}{llll}
\hline $\begin{array}{l}\text { Sample number and } \\
\text { laboratory code }\end{array}$ & $\begin{array}{l}\text { Depth below } \\
\text { surface }(\mathrm{m})\end{array}$ & $\begin{array}{l}\text { Depositional feature } \\
\text { sampled }\end{array}$ & $\begin{array}{l}\text { Age } \\
\text { (years) }\end{array}$ \\
\hline 1 (GLO3049) & 1.9 & bedrock core bar & $188 \pm 19$ \\
2 (GLO3050) & 3.5 & bedrock core bar & $390 \pm 59$ \\
$3($ GLO3051) & 1.92 & macro-channel lateral bar & $338 \pm 34$ \\
$4($ GLO3052) & 1.5 & bedrock core bar & $302 \pm 29$ \\
$5($ GLO3053) & 1.95 & macro-channel lateral bar & $175 \pm 36$ \\
6 (GLO3054) & 1.6 & macro-channel lateral bar & $609 \pm 216$ \\
7 (GLO3056) & 1.49 & bedrock core bar & $910 \pm 278$ \\
\hline
\end{tabular}

*Samples were prepared at the University of Gloucestershire Geochronology Laboratories, with multiple grain aliquots of quartz sand used for age determination.
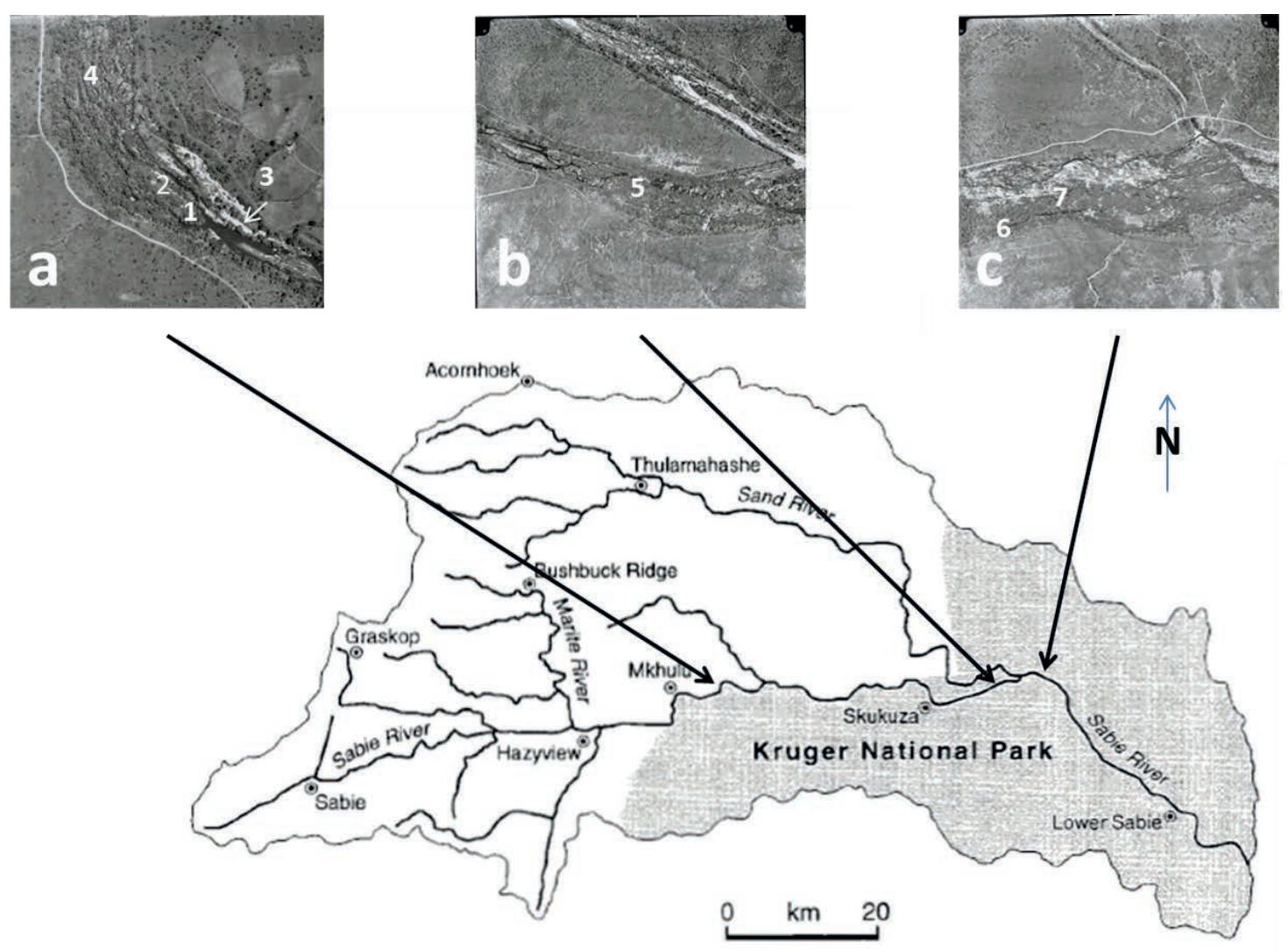

Fig. 3 Location map of optically stimulated luminescence samples collected from different depositional features on the Sabie River. Legend: 1- number of sample location in Table 2. 
The OSL ages are mainly within the 150-400 year range but extend to around 1000 years (Table 2), and indicate that, regardless of the depositional feature or reach, extensive stripping events (system 'resetting') have occurred within the last few hundred years. The results suggest that these rivers are essentially bedrock channels with any alluvial features that develop frequently being stripped on centennial timescales.

\section{SEMI-ARID, BEDROCK-INFLUENCED CHANNEL DEVELOPMENT}

A conceptual model of channel development (Fig. 4) shows the likely transitions between bedrock and alluvial states, based on the most frequent change directions observed on the Sabie and Olifants rivers. Although periods of extensive alluviation may have been witnessed historically, on longer (centennial) timescales the alluvial morphologies are frequently stripped, with the

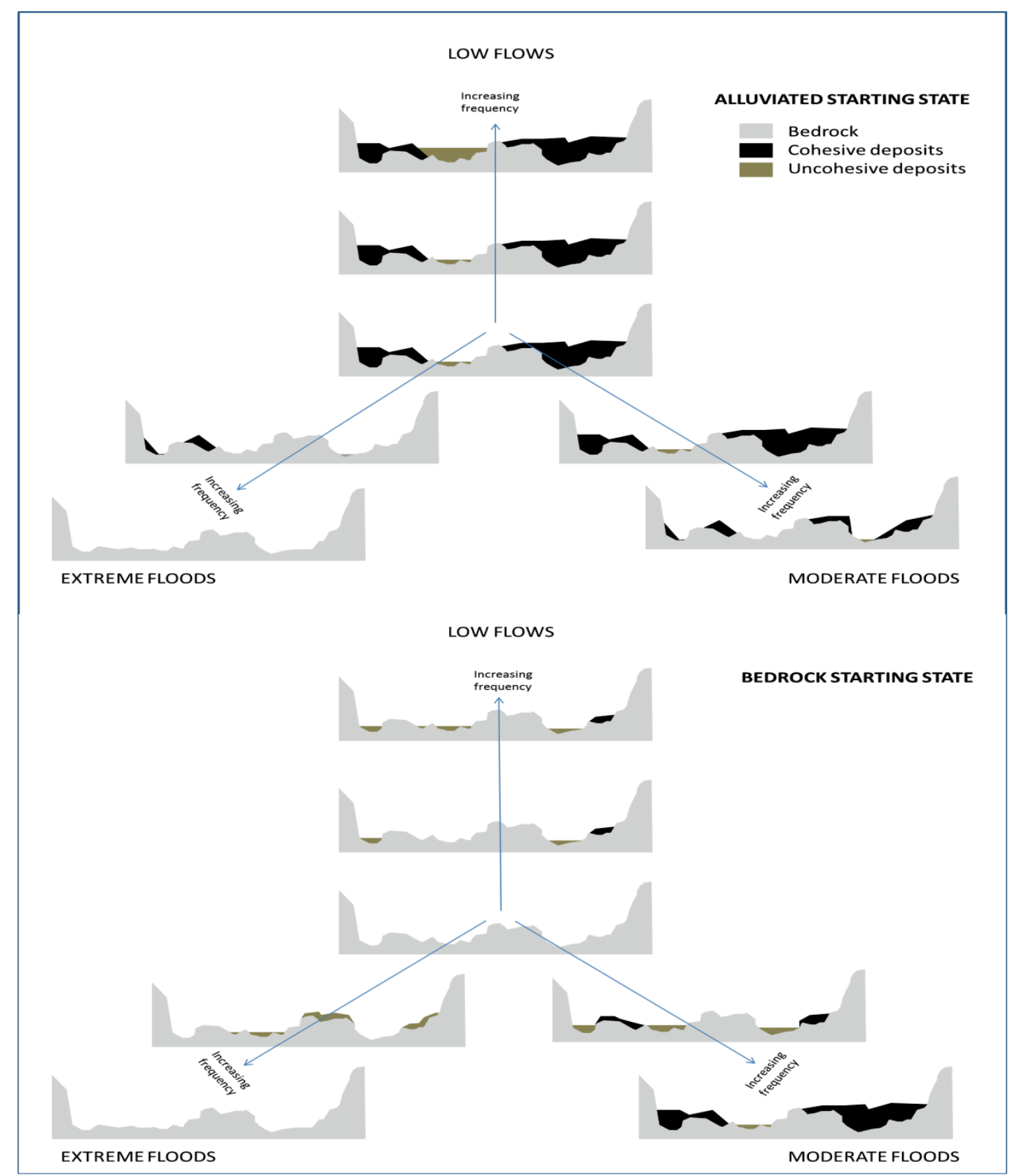

Fig. 4 A revised model of channel development for the Sabie and Olifants rivers, South Africa. Direction of change is from the central starting state outwards 
geological setting and extreme climatic influence creating conditions conducive to the continuing erosion and development of the bedrock macrochannel template. The model reflects the strong influence both of flood magnitude and frequency of flood occurrence in controlling morphologic development in these bedrock-influenced systems. In particular, closely-spaced extreme flood events - such as those in 2000 and 2012 - have been shown to result in truly catastrophic stripping of accumulated alluvial sediment and to alter the bedrock template, thereby controlling the longterm development of these systems.

\section{CONCLUSIONS}

Preliminary optically stimulated luminescence ages for remnant sediments on the Sabie River suggest that no deposits older than about 1000 years are present along the macrochannel, with most samples only 150-400 years old. Qualitative evidence of channel change in response to cyclone-generated flooding has also revealed that two extreme events spaced approximately a decade apart had the ability to cause extensive sediment stripping along both the Olifants and Sabie rivers. This suggests that the structural setting and extreme hydroclimatic influence on these two rivers create conditions conducive to the continuing erosion of the underlying bedrock macrochannel template on centennial timescales.

Acknowledgements This project was funded through NERC Urgency Grant NE/K001132/1. We would like to thank SANParks for supporting this research. We also thank Phil Toms (University of Gloucestershire) for luminescence sample analyses.

\section{REFERENCES}

Heritage, G., Large, A., Moon, B. \& Jewitt G (2004) Channel hydraulics and geomorphic effects of an extreme flood event on the Sabie River, South Africa. Catena 58, 151-181.

Rowntree, M., Heritage, G. and Rogers, K. (2001) In-channel metamorphosis of a mixed bedrock/alluvial river system In: Hydro-ecology: Linking Hydrology and Aquatic Ecology (ed. by Acreman, M.C.). IAHS Publ. 266, 113-125. IAHS Press, Wallingford, UK.

Tooth S. (2000) Process, form and change in dryland rivers: a review of recent research. Earth-Science Reviews 51, 67-107.

van Niekerk, A., Heritage, G. \& Moon, B. (1995) River classification for management: The geomorphology of the Sabie River. South African Geographical Journal 77(2), 68-76. 